\title{
Tolerance of cassava to post-emergence herbicides and determination of residues in the roots
}

\section{Tolerância da mandioca a herbicidas em pós-emergência e determinação dos resíduos nas raízes}

\author{
Eliete de Fátima Ferreira da ROSA ${ }^{1}$; Mikael Cardoso dos SANTOS ${ }^{2}$; Marcos André NOHATTO ${ }^{3}$; \\ Leonardo Geremias MADEIRA ${ }^{4}$; Fagner Barboza RAMOS ${ }^{5}$ \\ ${ }^{1}$ Autor para correspondência - Eng. Agr. Doutora em Manejo do Solo, Instituto Federal Catarinense Campus Santa Rosa do \\ Sul. Caixa Postal 04 - Santa Rosa do Sul-SC, eliete.rosa@ifc.edu.br \\ ${ }^{2}$ Acadêmico do curso de Engenharia Agronômica. Instituto Federal Catarinense Campus Santa Rosa do Sul. \\ mikaelsantos@outlook.com \\ ${ }^{3}$ Eng. Agr. Doutor em Fitossanidade, Instituto Federal Catarinense Campus Santa Rosa do Sul. marcos.nohatto@ifc.edu.br \\ ${ }^{4}$ Acadêmico do curso de Engenharia Agronômica. Instituto Federal Catarinense Campus Santa Rosa do Sul. \\ leo.geremiasmadeira@hotmail.com \\ ${ }^{5}$ Acadêmico do curso de Engenharia Agronômica. Instituto Federal Catarinense Campus Santa Rosa do Sul. \\ fagnerb.ramos@hotmail.com
}

Recebido em: 27-10-2019; Aceito em: 23-06-2020

\begin{abstract}
Assessing the tolerance of cassava to herbicides is essential for the development of weed management programs. Nevertheless, this assessment must include analyses of herbicide residues in the food so as to guarantee safety to the final consumer. Thus, this study evaluates the selectivity of cassava to different herbicides and quantifies pesticide residues in cassava roots (Manihot esculenta Crantz). The experimental design was randomized blocks with four replicates. The treatments were: control; mechanical weeding; bentazon (900 g a.i. ha- $\left.{ }^{-1}\right)$; mesotrione $\left(120 \mathrm{~g}\right.$ a.i. ha- $\left.{ }^{-1}\right)$; and imazethapyr (100 g a.i. ha- $\left.{ }^{-1}\right)$, applied in post-emergence. We used the herbicides clomazone $\left(1080 \mathrm{~g}\right.$ a.i. ha $\left.{ }^{-1}\right)$ and fluazifop (125 g a.i. ha $\left.{ }^{-1}\right)$ in pre-emergence and post-emergence, respectively, in all treatments. Throughout the crop cycle, we assessed the following: cassava intoxication at 10,20 , and 30 days after the application (DAA) of post-emergence herbicides; and plant height and stem diameter at $30 \mathrm{DAA}$. At the end of the crop cycle, we assessed the following: number of roots per plant; root length and diameter; root yield $(\mathrm{kg} / \mathrm{ha}) ;$ starch content (\%); and pesticide residues in cassava roots (multiresidue method). Despite its high phytotoxicity in the early development of cassava, mesotrione shows high selectivity and viability for weed control in this crop since, in general, it did not impair the other yield variables. Moreover, the study identified clomazone and sulfentrazone residues in cassava, indicating root contamination and high persistence of these herbicides in the environment.
\end{abstract}

Additional keywords: Manihot esculenta Crantz; pesticide residues; selectivity.

\begin{abstract}
Resumo
A avaliação da tolerância da mandioca aos herbicidas é fundamental para o desenvolvimento de programas de manejo de plantas daninhas na cultura, porém deve ser acompanhada de estudos de análise de resíduos no alimento, a fim de garantir a segurança ao consumidor final. Diante disso, o objetivo foi avaliar a seletividade da cultura a diferentes herbicidas; e quantificar os resíduos de agrotóxicos nas raízes de mandioca (Manihot esculenta Crantz). O experimento foi conduzido em delineamento em blocos casualizados, com quatro repetições. Os tratamentos foram: testemunha; capina mecânica; bentazon (900 g i.a. ha- $\left.{ }^{-1}\right)$; mesotrione (120 g i.a. ha $\left.{ }^{-1}\right)$ e imazethapyr (100 g i.a. ha $\left.{ }^{-1}\right)$ aplicados em pós-emergência. Os herbicidas clomazone $\left(1080 \mathrm{~g}\right.$ i.a. ha $\left.{ }^{-1}\right)$ e fluazifope (125 g i.a. ha ${ }^{-1}$ ) foram utilizados em pré-emergência e pós-emergência, respectivamente, em todos os tratamentos. As variáveis avaliadas foram: intoxicação da cultura aos 10, 20 e 30 dias após a aplicação dos herbicidas pós-emergentes (DAA); estatura das plantas e diâmetro do caule, aos 30 DAA. Ao final do ciclo da cultura, foram avaliados: número de raízes por planta; comprimento e diâmetro de raízes; produtividade de raízes ( $\mathrm{kg} / \mathrm{ha})$, teor de amido (\%) e determinação de resíduos de agrotóxicos em raízes de mandioca (método multirresíduos). 0 mesotrione, apesar da elevada fitotoxicidade na fase inicial, demonstra maior seletividade e possibilidade de utilização no controle de plantas daninhas na cultura, uma vez que, em geral, não prejudicou as demais variáveis produtivas. Ainda, identificou-se a detecção de resíduos de clomazone e sulfentrazone na mandioca, indicando contaminação nas raízes e alta persistência desses herbicidas no ambiente.
\end{abstract}

Palavras-chave adicionais: Manihot esculenta Crantz; resíduos de agrotóxicos; seletividade. 


\section{Introduction}

Cassava (Manihot esculenta Crantz) plays an important role in the human diet (CONAB, 2020). Its production targets mainly the manufacture of flour and starch and its fresh consumption. Brazil is the world's fifth largest producer of cassava, with a production of 18.8 million tons in an area of 1.3 million hectares (FAOSTAT, 2017). Such figures reveal a low yield $\left(14.4 \mathrm{t} \mathrm{ha}^{-1}\right)$ despite the high yield potential of the crop, which reaches values above $100 \mathrm{t} \mathrm{ha}^{-1}$ in some regions (Alves, 2007).

Among the factors concerning the low yield in the field, losses resulting from weed competition stand out. Given their rusticity context, producers usually believe that they do not need to worry about the phytosanitary management of crops. This is an extremely mistaken decision making since studies indicate a yield reduction of practically $100 \%$ due to weed interference (Johanns \& Contiero, 2006).

Chemical weed control is a fast, effective, and interesting cost-benefit alternative. Notwithstanding, there are few registered herbicides for cassava, most of which are pre-emergence herbicides (AGROFIT, 2020). The most common agricultural system for cassava is family farming, which reduces the interest and investment of large multinational companies to register and develop molecules for use in this crop.

The search for selective herbicides capable of eliminating weeds without causing phytotoxic effects to the crop is fundamental to expand management options for the farmer and to increase its yield potential. However, this should not be the only concern of the professionals in the area.

Selectivity studies on cassava do not evaluate possible pesticide residues in the food after application (Agostinetto et al., 2002; Biffe et al., 2010; Silva et al., 2012). This determination is extremely important to assess the risks arising from the use of pesticides regarding contaminated food and organisms. It provides useful information to assist in the development of prevention programs, risk control, and regulation of foreign trade, ensuring safety to the population.

Therefore, this study evaluates the selectivity of cassava to different herbicides with the following mechanisms of action (Senseman, 2007): bentazon (photosystem II inhibitor), mesotrione (carotenoid inhibitor), and imazethapyr (acetolactate synthase inhibitor). The study also quantifies pesticide residues in the roots at the end of the crop cycle.

\section{Materials and Methods}

We conducted the experiment in an agricultural area (29 $03^{\circ} 34.9^{\prime \prime} \mathrm{S}, 49^{\circ} 36^{\prime} 19.8^{\prime \prime} \mathrm{W}$, and approximate altitude of 14 meters) in Sombrio city, Santa Catarina State, Brazil, from September 2018 to July 2019. The soil in the area is a Quartzarenic Neosol with sandy texture (EMBRAPA, 2013), and the previous crop was tobacco (Nicotiana tabacum L.). The relief is flat and, according to the Köppen classification (Ometto, 1981), the climate of the region is Cwa type, humid mesothermal subtropical.

The soil had the following chemical characteristics: $\mathrm{pH}\left(\mathrm{CaCl}_{2}\right)=5.2$; $\mathrm{SMP}$ index $=6.7$; phosphorus = $=466 \mathrm{mg} \mathrm{dm}^{-3} ;$ potassium $=159 \mathrm{mg} \mathrm{dm}^{-3}$; calcium = $=1.8 \mathrm{cmolc}_{\mathrm{dm}}{ }^{-3}$; magnesium $=1.2 \mathrm{cmolc}_{\mathrm{cm}}{ }^{-3}$, aluminum $=0.1 \mathrm{cmol}_{\mathrm{c}} \mathrm{dm}^{-3}$; and soil organic matter $=2.1 \%$. Soil analysis showed no need for base fertilization and liming. However, we performed cover fertilization at 45 days after planting, using $20 \mathrm{~kg} \mathrm{~N}^{-1}$ (CQFS, 2016).

The experimental design was randomized blocks with four replicates. The treatments were: control; mechanical weeding (we weeded the plants with the aid of a hoe until the last herbicide application, in January 2019); and bentazon (900 grams of active ingredient per hectare), mesotrione (120 g a.i. ha $\left.{ }^{-1}\right)$ and imazethapyr (100 g a.i. ha $\left.{ }^{-1}\right)$, applied in post-emergence. We chose these herbicides and doses from their effectiveness in controlling broadleaf weeds. Two post-emergence applications took place throughout the cycle, from which we used mean phytotoxicity values for statistical analysis.

We used the herbicides clomazone $\left(1080 \mathrm{~g}\right.$ a.i. ha $\left.^{-1}\right)$ and fluazifop (125 g a.i. ha- ${ }^{-1}$ ) in pre-emergence and post-emergence, respectively, in all treatments, considering it to be a standard management due to the frequent use of producers in the region.

The plots were $2.4 \mathrm{~m}$ long and $3.6 \mathrm{~m}$ wide, with four rows. For the evaluations, we considered the two central rows as the working area, discarding a plant at each end. Thus, each plot presented six useful plants in the evaluations.

Planting took place in October. For that, we used $21 \mathrm{~cm}$ long (Viana et al., 2002) stem cuttings of the cultivar Sangão (SCS-253). We planted the stem cuttings horizontally in $5 \mathrm{~cm}$ deep furrows, at a spacing of $0.60 \mathrm{~m}$. At about 30 days before planting, we cleared the cultural remains of the previous crop, desiccating the entire area with the herbicide glyphosate (1440 g a.i. ha- ${ }^{-1}$ ).

At 10,20 , and 30 days after the application (DAA) of post-emergence herbicides, we assessed crop intoxication visually using a percentage scale ranging from 0 (zero) to 100 (one hundred), where 0 implies the absence of any injuries and 100 corresponds to plant death. At $30 \mathrm{DAA}$, we assessed first branch height $(\mathrm{m})$ and stem diameter (cm; with the aid of a digital caliper).

At 10 months after planting, we harvested the plants and assessed the following variables: number of roots per plant; root length and diameter $(\mathrm{m})$; root yield $\left(\mathrm{kg} \mathrm{ha}^{-1}\right)$; and starch content (\%), with the aid of a hydrostatic balance (Grossman \& Freitas, 1950, adapted by Oliveira et al., 2011). For the latter, we used the following equations: $\mathrm{DW}=15.75+0.0564 \mathrm{x}$, wherein DW is the dry weight (\%) and "x" is the weight of $3 \mathrm{~kg}$ of fresh cassava in water; Starch content $=\mathrm{DW}-4.65$.

We identified samples from each experimental plot and sent them to the Laboratory for Analysis of Pesticide Residues (TECPAR - Curitiba/PR) (with the exception of the bentazon and imazethapyr treatments, 
due to insufficient material) for the verification of possible pesticide residues in the cassava roots. These samples consisted of $0.5 \mathrm{~kg}$ of fresh cassava, which we stored after harvest in a refrigerator (temperature between $4-5^{\circ} \mathrm{C}$ ) until transport. During transport, according to the guidelines of the company, the samples remained in a thermal box with ice. The laboratory used liquid chromatography for the determination of pesticide residues, with detection by sequential mass spectrometry - LC-MS/MS multiresidue method.

We submitted the data to analysis of variance $(p \leq 0.05)$. In the case of statistical significance, we compared the means using the Tukey test $(p \leq 0.05)$, except for the evaluation of pesticide residues, which consisted of descriptive analysis.

\section{Results and Discussion}

Regarding phytotoxicity, at 10 DAA, imazethapyr caused less injury than the herbicides bentazon and mesotrione (Table 1). This result is possibly due to the greater systemic action of imazethapyr, where the symptoms become more apparent after weeks of application. This proved to be true after analyzing the last evaluation of this variable (30 DAA), when the herbicide, which belongs to the group of acetolactate synthase (ALS) inhibitors, showed high phytotoxicity values. These values were similar to those of the other herbicides, indicating that the products had a high phytotoxic effect.

Table 1 - Phytotoxicity (\%) resulting from bentazon (900 g a.i. ha $\left.{ }^{-1}\right)$; mesotrione (120 g a.i. ha $\left.{ }^{-1}\right)$ and imazethapyr $\left(100 \mathrm{~g}\right.$ a.i. ha $\left.{ }^{-1}\right)$ herbicides; besides the control and weeding, to the cassava culture, evaluated at 10,20 and 30 days after the application of the treatments (DAA).

\begin{tabular}{|c|c|c|c|}
\hline Treatment & 10 DAA & 20 DAA & 30 DAA \\
\hline Control & $0.00 c^{1}$ & $0.00 \mathrm{~b}$ & $0.00 \mathrm{c}$ \\
\hline Weeding & $0.00 \mathrm{c}$ & $0.00 \mathrm{~b}$ & $0.00 \mathrm{c}$ \\
\hline Bentazon & $13.75 b$ & $35.00 \mathrm{a}$ & $75.00 \mathrm{~b}$ \\
\hline Mesotrione & $33.75 \mathrm{a}$ & $45.00 \mathrm{a}$ & $80.00 a b$ \\
\hline Imazethapyr & $5.00 \mathrm{c}$ & $38.75 \mathrm{a}$ & $82.50 \mathrm{a}$ \\
\hline CV (\%) & 28.83 & 23.53 & 6.07 \\
\hline
\end{tabular}

${ }^{1}$ Means followed by the same letters in the columns do not differ from each other by the Tukey test at $5 \%$ probability.

Silva et al. (2012) indicate the selectivity of cassava to post-emergence application of the herbicides mesotrione, bentazon, and trifloxysulfuron-sodium (the latter belonging to the group of ALS inhibitors, the same mechanism of action of imazethapyr). The authors found intoxication values below $7 \%$; contrasting with the results of the present study. A hypothesis is that, in the present study, the higher dosage and the climatic stress conditions resulting from the drought period that the crop went through decreased its tolerance to the herbicides. This suggests that these factors directly influence plant behavior in response to the treatment for weed control.

Weed interference affected stem diameter since the control shows a $71.65 \%$ reduction in this variable in relation to weeding (Table 2). However, the herbicide treatments did not differ from the control for this variable, with the exception of mesotrione. This herbicide also did not affect plant height in comparison to the control and weeding treatments (without herbicide application) (Table 2). This indicates greater tolerance of the crop to this herbicide in relation to the other products. Similarly, Silveira et al. (2012) report that none of the mesotrione doses influenced plant height, stem diameter, number of leaves, leaf area, dry matter accumulation of leaves, stems, and roots, and total dry matter.

Table 2 - Stem diameter $(\mathrm{cm})$ and height $(\mathrm{m})$ resulting from bentazon $\left(900 \mathrm{~g}\right.$ a.i. ha- $\left.{ }^{-1}\right)$; mesotrione $\left(120 \mathrm{~g}_{\text {a.i. }}\right.$ ha $\left.^{-1}\right)$ e imazethapyr ( $100 \mathrm{~g}$ a.i. ha ${ }^{-1}$ ) herbicides; besides the control and weeding, to the cassava culture, evaluated at 30 days after the application of the treatments.

\begin{tabular}{lcc}
\hline Treatment & Stem diameter $(\mathrm{cm})$ & Height $(\mathrm{m})$ \\
\hline Control & $2.18 \mathrm{c}^{1}$ & $0.32 \mathrm{a}$ \\
Weeding & $7.69 \mathrm{a}$ & $0.35 \mathrm{a}$ \\
Bentazon & $3.57 \mathrm{bc}$ & $0.05 \mathrm{~b}$ \\
Mesotrione & $4.50 \mathrm{~b}$ & $0.24 \mathrm{a}$ \\
Imazethapyr & $3.04 \mathrm{bc}$ & $0.06 \mathrm{~b}$ \\
\hline CV $(\%)$ & 24.48 & 26.24
\end{tabular}

${ }^{1}$ Means followed by the same letters in the columns do not differ from each other by the Tukey test at $5 \%$ probability

Table 3 shows that the values occurring at the end of the cycle for the crop were generally below expectations, possibly due to the low rainfall rates in the period (data not shown). For the variables number of roots per plant, average root length, average root diameter, root yield, and starch content, the weeding and mesotrione treatments showed similar behavior.
This is because the plants recovered even with the apparent initial phytotoxicity after mesotrione application (Table 1). In turn, the plants that received bentazon and imazethapyr failed to complete the cycle, hampered by the severe damage of these herbicides.

The results of the analysis of pesticide residues led to an estimate of human exposure to pesticides in 
fresh food, which Table 4 shows along with the maximum residue limits (MRL) established by the National Health Surveillance Agency (ANVISA, 2015). The main herbicide in this analysis was clomazone, a carotenoid inhibitor present in all pre-emergence treatments of this experiment. Its maximum allowed limit is $0.05 \mathrm{mg} \mathrm{kg}^{-1}$, and the control treatment showed higher values.

Table 3 - Number of roots per plant (NRP), root length (RL), root diameter (RD), yield (kg/ha) and starch content (\%) resulting from bentazon (900 $\mathrm{g}$ a.i. ha $\left.{ }^{-1}\right)$; mesotrione $\left(120 \mathrm{~g}\right.$ a.i. ha $\left.{ }^{-1}\right)$ and imazethapyr $\left(100 \mathrm{~g}\right.$ a.i. ha $\left.{ }^{-1}\right)$ herbicides; $^{\text {; }}$ besides the control and weeding, to the cassava crop, evaluated at 275 days after planting.

\begin{tabular}{lccccc}
\hline Treatment & NRP & RL $(\mathrm{m})$ & RD $(\mathrm{m})$ & ${\text { Yield }\left(\mathrm{kg} \mathrm{ha}^{-1}\right)}^{\text {Starch }(\%)}$ \\
\hline Control & $1.78 \mathrm{ab}^{1}$ & $0.09 \mathrm{ab}$ & $0.09 \mathrm{bc}$ & $157.69 \mathrm{~b}$ & $6.03 \mathrm{ab}$ \\
Weeding & $3.31 \mathrm{a}$ & $0.17 \mathrm{a}$ & $0.29 \mathrm{a}$ & $1039.23 \mathrm{a}$ & $11.11 \mathrm{a}$ \\
Bentazon & $0.00 \mathrm{~b}$ & $0.00 \mathrm{~b}$ & $0.00 \mathrm{c}$ & $0.00 \mathrm{~b}$ & $0.00 \mathrm{~b}$ \\
Mesotrione & $3.16 \mathrm{a}$ & $0.16 \mathrm{a}$ & $0.23 \mathrm{ab}$ & $651.85 \mathrm{ab}$ & $11.84 \mathrm{a}$ \\
Imazethapyr & $0.00 \mathrm{~b}$ & $0.00 \mathrm{~b}$ & $0.00 \mathrm{c}$ & $0.00 \mathrm{~b}$ & $0.00 \mathrm{~b}$ \\
\hline CV (\%) & 46.24 & 32.12 & 20.59 & 46.44 & 23.34 \\
\hline
\end{tabular}

${ }^{1}$ Means followed by the same letters in the columns do not differ from each other by the Tukey test at $5 \%$ probability.

Studies identify risks from the use of clomazone, pointing to the capacity of this herbicide to induce oxidative stress and inhibit erythrocytes in humans (Santi et al., 2011). Moreover, it has a toxic effect on fish such as Prochilodus lineatus (Valenciennes, 1837), leading to hematological and biochemical changes in the species (Pereira et al., 2013); and on microbial populations, decreasing the abundance of microorganisms and nitrogen-fixing bacteria (Du et al., 2018).

The physicochemical characteristics of the herbicide are also important since they indicate high solubility $\left(S=1100 \mathrm{mg} \mathrm{L}^{-1}\right)$ and moderate affinity with organic matter (Koc $=300 \mathrm{~mL} \mathrm{~g}^{-1}$ ) (Senseman, 2007). Along with these factors, the soil conditions in the experimental region (low $\mathrm{pH}$ and organic matter) enhance herbicide leaching (Pereira et al., 2017). This leads to possible problems of groundwater contamination and exposure risks for humans.

The second most important herbicide in the analysis was sulfentrazone, which is a protoporphyrinogen oxidase (Protox) inhibitor (Senseman, 2007). Its concentration was $0.02 \mathrm{mg} \mathrm{kg}^{-1}$ (Table 4). Interestingly, the present experiment did not include this herbicide. Its detection was possibly due to the history of the experimental area since the previous crop was tobacco and its management included the use of this product. In addition, this herbicide has a long half-life (time in which the compound decreases by $50 \%$ ) in the soil, reaching values of 302 days (Senseman, 2007). This certainly contributes to the persistence of the herbicide in the environment, increasing the risk of contamination to the subsequent crop (cassava).

Studies also report possible problems arising from the use of sulfentrazone, with a negative effect on the neurological development of rats exposed to this herbicide (Castro et al., 2007). Furthermore, sulfentrazone is an endocrine disruptor (Ahmad et al., 2017), that is, it interferes with the synthesis, release, transport, binding, action, or elimination of natural hormones in the body, which are responsible for the maintenance of homeostasis, reproduction, development, and/or behavior (Crisp et al., 1998). There is a particular concern about endocrine disrupting pesticides as they are metabolism-resistant and bioaccumulate through the food chain. They can concentrate in body fats and move to the developing offspring and/or newborns through breast milk (Bila \& Dezotti, 2007).

Table 4 - Pesticide residues in cassava roots resulting from the treatment with mesotrione herbicide $(120 \mathrm{~g}$ a.i. ha-1 $)$; beyond the control and weeding.

\begin{tabular}{lcccc}
\hline Parameter ${ }^{1}$ & $\begin{array}{c}\mathrm{MRL}^{2} \\
\left(\mathrm{mg} \mathrm{kg}^{-1}\right)\end{array}$ & Control & $\begin{array}{c}\text { Treatments } \\
\text { Weeding }\end{array}$ & Mesotrione \\
\hline Bifentrina & 2 & $<\mathrm{LQ}$ & $*$ & $*$ \\
Clomazone & 0.05 & 0.06 & 0.02 & 0.04 \\
Metolacloro & Not authorized & $<\mathrm{LQ}$ & $*$ & $<\mathrm{LQ}$ \\
Fluazifope-p-butílico & 0.02 & $<\mathrm{LQ}$ & $*$ & $*$ \\
Sulfentrazone & Not authorized & $<\mathrm{LQ}$ & $<\mathrm{LQ}$ & 0.02 \\
Clorpirifós & Not authorized & $*$ & $\mathrm{LQ}$ \\
\hline
\end{tabular}

${ }^{1}$ The other active ingredients researched were not detected in the analyzed material; ${ }^{2} \mathrm{MRL}$ - Maximum residue level recommended by the Brazilian Health Regulatory Agency - ANVISA; $<$ LQ - detected at a concentration lower than the limit of quantification; * Pesticide not identified in sampling.

The herbicide can also affect the symbiosis between rhizobia and legumes, reducing amino acids and nitrate concentration in xylem sap. This leads to less production and less amount of photoassimilates in nodules, which impairs nitrogen assimilation and fixation in soybean plants (Arruda et al., 2001).

\section{Conclusions}

Despite its high phytotoxicity in the early development of cassava, mesotrione shows high selectivity and viability for weed control in this crop since, in general, it did not impair the other yield variables. 
Moreover, the study identified clomazone and sulfentrazone residues in cassava, indicating root contamination and high persistence of these herbicides in the environment.

\section{References}

Agostinetto D, Fleck NG, Rizzardi MA, Thomas AL (2002) Seletividade de herbicidas latifolicidas aplicados à mandioca em pós-emergência. Revista Brasileira de Herbicidas

doi: https://doi.org/10.7824/rbh.v3i1.370

3(1):39-43.

AGROFIT - Ministério da Agricultura, Pecuária e Abastecimento (2020). Disponível em:

http://www.agricultura.gov.br/224erviços-e-siste-

mas/sistemas/agrofit (Acesso em 27 mai 2020).

Ahmad Ml, Usman A, Ahmad M (2017) Computational study involving identification of endocrine disrupting potential of herbicides: Its implication in TDS and cancer progression in CRPC patients. Chemosphere 173:395403. doi: 10.1016/j.chemosphere.2017.01.054

Alves RNB (2007) O trio da produtividade na cultura da mandioca. Disponível em: <http://www.cnpma.embrapa.br/boaspraticas/download/Trio_Produtividade_Cultura_Mandioca.pdf>. (Acesso em: 10 nov 2017)

ANVISA - Agência Nacional de Vigilância Sanitária. Lista de referência de limites máximos de resíduos (LMRs) para as culturas do PARA (2015). Disponível em: <http://portal.anvisa.gov.br/programa-de-analisede-registro-de-agrotoxicos-para> (Acesso em $27 \mathrm{mai}$ 2020).

Arruda JS, Lopes NF, Bacarin MA (2001) Nodulação e fixação do nitrogênio em soja tratada com sulfentrazona. Pesquisa Agropecuária Brasileira 36(2):325-330. doi: 204X2001000200016

Biffe, DF, Constantin J, Oliveira Jr. RS, Rios FA, Franchini LHM, Gemelli A, Arantes JGZ Raimondi, MA, Blainski E (2010). Avaliação de herbicidas para dois cultivares de mandioca. Revista Sociedade Brasileira da Ciência das Plantas Daninhas 28(4):807-816. doi: https://doi.org/10.1590/S0100-83582010000400014

Bila DM, Dezotti M (2007) Desreguladores endócrinos no meio ambiente: efeitos e consequências. Revista Química Nova 30(3):651-666. doi: https://doi.org/10.1590/S0100-40422007000300027

Castro VLSS, Destefani CR, Diniz C, Poli C (2007) Evaluation of neurodevelopmental effects on rats exposed prenatally to sulfentrazone. Neurotoxicology 28(6):1249-1259.

doi:
CONAB - Companhia Nacional de Abastecimento (2017) Mandioca: raiz, farinha e fécula. Disponível em: $<$ https://www.conab.gov.br/info-agro/analises-do-mercado-agropecuario-e-extrativista/analises-do-mercado/historico-mensal-de-andioca/item/download/15257_cbda3c716a5046d0700dc8 31c240a234 > (Acesso em 27 mai 2020).

CQFS - Comissão de Química e Fertilidade do Solo RS/SC (2016) Manual de calagem e adubação para os Estados do Rio Grande do Sul e de Santa Catarina. SBCS. $376 \mathrm{p}$.

Crisp TM, Clegg ED, Cooper RL, Wood WP, Anderson DG, Baetcke KP, Hoffmann JL, Morrow MS, Rodier DJ, Schaeffer JE, Touart LW, Zeeman MG, Patel YM (1998) Environmental endocrine disruption: an effects assessment and analysis. Environmental Health Perspectives 106(1):11-56. doi: https://doi.org/10.1289/ehp.98106s111

Du P, Wu X, Xu J, Dong F, Liu X, Zhang Y, Zheng Y (2018) Clomazone influence soil microbial community and soil nitrogen cycling. Science of The Total Environment 644(10):475-485. doi: https://doi.org/10.1016/j.scitotenv.2018.06.214

EMBRAPA - Empresa Brasileira de Pesquisa Agropecuária (2013) Sistema brasileiro de classificação de solos. Embrapa Solos. 353p.

FAOSTAT - Food and Agriculture Organization of The United Nations Satatistics Division (2017), Available at: <http://www.fao.org/faostat/en/ > (accessed: 10 out 2019).

Johanns O, Contiero RL (2006). Efeitos de diferentes períodos de controle e convivência de plantas daninhas com a cultura da mandioca. Revista Ciência Agronômica 37(3) 326-331.

Ometto JC (1981) Bioclimatologia tropical. Ceres. p.390-398.

Oliveira NT, Alves JMA, Uchôa SCP, Rodrigues GS, Melville CC, Albuquerque JAA (2011) Caracterização e identificação de clones de mandioca produzidos em Roraima para o consumo in natura. Revista Agro@mbiente On-line 5(3):188-193. doi: http://dx.doi.org/10.18227/1982-8470ragro.v5i3.624

Pereira GAM, Barcellos JR, Gonçalves VA, Silva DV, Silva AA (2017) Clomazone leaching estimate in soil columns using the biological method. Planta Daninha 35(0):1-7. doi: http://dx.doi.org/10.1590/s010083582017350100024

Pereira L, Fernandes MN, Martinez CBR (2013) Hematological and biochemical alterations in the fish Prochilodus lineatus caused by the herbicide clomazone. Environmental Toxicology and Pharmacology 36(1):1-8.

https://doi.org/10.1016/j.etap.2013.02.019 
Santi A, Menezes C, Duarte MMF, Leitemperger J, Lópes T, Loro VL (2011). Oxidative stress biomarkers and acetylcholinesterase activity in human erythrocytes exposed to clomazone (in vitro). Interdisciplinary Toxicology 4(3):149-153.

https://doi.org/10.2478/v10102-011-0023-9

Senseman SA. Herbicide handbook (2007), 9.ed, Weed Science Society of America, 458p.

Silva DV, Santos JB, Carvalho FP, Ferreira EA, França AC, Fernandes JSC, Gandini EMM, Cunha VC (2012). Seletividade de herbicidas pós-emergentes na cultura da mandioca. Planta Daninha 30(4) 835-841. doi: http://dx.doi.org/10.1590/S0100-83582012000400018
Silveira HM, Silva DV, Santos JB, Neto MDC, Ferreira EA, Carvalho FP, Silva AA, Sediyama T (2012) Sensibilidade de cultivares de mandioca ao herbicida mesotrione. Revista Brasileira de Herbicidas 11(1):24-31. doi: https://doi.org/10.7824/rbh.v11i1.128

Viana AES, Sediyama T, Cecon PR, Lopes SC, Sediyama MAN (2002). Estimativas de tamanho de parcela em experimentos com mandioca. Horticultura Brasileira 20(1):58-63. doi: http://dx.doi.org/10.1590/S010205362002000100011 